\title{
RESEARCH NOTE \\ Carryover of tembotrione and atrazine in sugar beet
}

\author{
Gabriella Daier Oliveira Pessoa Carneiro으, Amanda Ferreira Bontempo², \\ Fernanda Aparecida Rodrigues Guimarães ${ }^{3}$, Marcelo Rodrigues dos \\ Reis $^{2}$, Daniel Valadão Silva ${ }^{1}$, Matheus de Freitas Souzaํㅜ, and Hamurábi \\ Anizio Lins ${ }^{1}$ \\ ${ }^{1}$ Universidade Federal Rural do Semi-Árido, Department of Agronomic and Forest Sciences. Mossoró, Rio \\ Grande do Norte, 59625-900, Brazil. \\ ${ }^{2}$ Universidade Federal de Viçosa, Department of Crop Production. Rio Paranaíba, Minas Gerais, 38810-000, \\ Brazil. \\ 3Universidade Federal de Viçosa, Department of Crop Production. Viçosa, Minas Gerais, 36570-000, \\ Brazil.
}

\begin{abstract}
G.D. Oliveira Pessoa Carneiro, A. Ferreira Bontempo, F.A. Rodrigues Guimarães, M. Rodrigues dos Reis, D. Valadão Silva, M. de Freitas Souza, and H. Anizio Lins. 2019. Carryover of tembotrione and atrazine in sugar beet. Cien. Inv. Agr. 46(3): 319-324. A field experiment was performed to determine the effects of tembotrione and atrazine residues in soil on sugar beet eight months after herbicide application. The treatments included sugar beet cultivation with tembotrione-contaminated soil (50.4 $\mathrm{g}$ a.i. ha $\left.{ }^{-1}\right)$, tembotrione (100.8 $\mathrm{g}$ a.i. $\left.\mathrm{ha}^{-1}\right)$, tembotrione and atrazine $\left(50.4 \mathrm{~g}\right.$ a.i. $\mathrm{ha}^{-1}+2 \mathrm{~L}$ a.i. ha $\left.{ }^{-1}\right)$, tembotrione and atrazine $(100.8 \mathrm{~g}$ a.i. $\mathrm{ha}^{-1}+2 \mathrm{~L}$ a.i. ha $\left.{ }^{-1}\right)$, atrazine $\left(2 \mathrm{~L}\right.$ a.i. $\left.\mathrm{ha}^{-1}\right)$ and soil without herbicide application. In general, in comparison to the control, when sugar beets were grown following any of the herbicide treatments, the crop dry biomass was reduced. However, only treatments sprayed with a high rate of tembotrione significantly reduced sugar beet yield.
\end{abstract}

Keywords: Atrazine, Beta vulgaris L., carryover, tembotrione.

\section{Introduction}

Herbicides with high persistence in soil can cause phytotoxicity in sensitive crops cultivated in succession. This phenomenon is known as a carryover or residual effect (Mancuso et al., 2011). This residual effect is the main factor that impairs

Received Aug 10, 2018. Accepted Aug 07, 2019. Corresponding author: hamurabi_a_@hotmail.com crop succession. Although visible crop injury may not be apparent, persistent herbicides may result in reduced growth and crop yields, even in conditions of low herbicide concentrations in soil (Silva et al., 2013), and cause inadvertent chemical residues in harvested crops. In Brazil, annual crops such as corn and soybean are often grown in immediate succession and are subject to herbicides remaining from a previous crop. The response of vegetable crops to these herbicide 
residues in soil depends upon the herbicide (Felix and Doohan, 2005), the species and cultivar (Felix et al., 2007), soil texture, $\mathrm{pH}$, soil organic matter (Ismail and Ahmad, 1994) rainfall, and temperature.

Tembotrione inhibits the enzyme 4-hydroxyphenylpyruvate dioxygenase (HPPD) and causes bleaching in susceptible plants. Tembotrione is registered for weed control in corn and is often applied in combination with atrazine, a photosystem II (PSII) inhibitor (MAPA, 2019). Few studies exist regarding tembotrione carryover to succeeding crops (Bomtempo et al., 2016), while there are many reports of carryover available for other 'bleaching' herbicides that inhibit pigment synthesis (clomazone, mesotrione and isoxaflutole) in species including sugar beets, cabbage, tomato and potato (Robinson, 2008). Atrazine residues can also damage certain susceptible crops (USDA, 2015). Crops such as garlic, onion, potato and carrot showed reduced yields even two years after atrazine application (Robinson, 2008).

According to the tembotrione label marketed for Brazil, a sowing interval greater than 30 days after application is recommended prior to planting crops such as sunflower, cotton and dry bean, but there are no similar sowing restrictions listed for vegetable crops (MAPA, 2019). However, on the label of the same commercial product in the United States of America, an interval of 18 months is recommended prior to sowing sugar beet in soils treated with tembotrione (USDA, 2015). Unfortunately, the lack of information regarding the behavior of tembotrione in tropical soils makes it difficult to estimate the degree of injury that might be caused to a vegetable crop planted following tembotrione application in Brazil.

This study was designed to evaluate the growth and productivity of sugar beet planted eight months after application of atrazine and tembotrione to determine the degree of herbicide carryover in Brazilian cropping systems.

\section{Materials and methods}

A sugar beet carryover experiment was conducted between August and December 2014 at the experimental field station of the Federal University of Viçosa - Campus Rio Paranaíba, Minas Gerais. Before sowing sugar beet, the experimental area was planted with corn (DKB-390 variety VT PRO II) on 15 November 2013. The herbicides tembotrione (50.4 $\mathrm{g}$ a.i.ha $\left.\mathrm{a}^{-1}\right)$, tembotrione ( $100.8 \mathrm{~g}$ a.i.ha $\left.{ }^{-1}\right)$, tembotrione and atrazine (50.4 g a.i.ha ${ }^{-1}$ $+2 \mathrm{~kg}$ i.a.ha $\left.\mathrm{h}^{-1}\right)$, tembotrione and atrazine (100.8 ga.i.ha ${ }^{-1}+2 \mathrm{~kg}$ a.i.ha $\left.{ }^{-1}\right)$, and atrazine ( $2 \mathrm{~kg}$ a.i.ha $\left.{ }^{-1}\right)$ - were applied to corn at V2 using the sprayer PJ 401 Jacto $^{\circledR}$ with four TT11002 nozzles spaced $0.50 \mathrm{~m}$ apart and at a pressure of $172.37 \mathrm{kPa}$. The experimental area had no history of herbicide application prior to planting corn, and only manual weed control was performed for the potato crop.

The experiment was performed in a randomized block design with five replications. The treatments included sugar beet cultivation in soil, eight months after application of the five tembotrione treatments listed above. An additional treatment was added as a control and had no herbicide applied. Each plot consisted of four double sugar beet rows $(1.75 \mathrm{~m}$ wide by $15 \mathrm{~m}$ long), totaling $26.25 \mathrm{~m}^{2}$. At sugar beet harvest, only $10 \mathrm{~m}$ of the two central double rows were evaluated. The outer $2.5 \mathrm{~m}$, totaling $5 \mathrm{~m}$, was excluded to avoid any yield variability resulting from the increase in light penetration.

The experimental soil area was classified as clay (67\% clay), and its chemical properties are presented in Table 1. Soil preparation prior to sugar beet planting included subsoiling followed by harrowing and rotary tilling. Fertilizer was applied at planting with $800 \mathrm{~kg} \mathrm{ha}^{-1}$ monoammonium phosphate $\left(80 \mathrm{~kg} \mathrm{ha}^{-1} \mathrm{~N}\right.$ and $\left.384 \mathrm{~kg} \mathrm{ha}^{-1} \mathrm{P}_{2} \mathrm{O}_{5}\right), 200$ $\mathrm{kg} \mathrm{ha}^{-1}$ potassium chloride $\left(120 \mathrm{~kg} \mathrm{ha}^{-1} \mathrm{~K}_{2} \mathrm{O}\right)$ and $1500 \mathrm{~kg} \mathrm{ha}^{-1}$ superphosphate $\left(270 \mathrm{~kg} \mathrm{ha}^{-1} \mathrm{P}_{2} \mathrm{O}_{5}\right)$.

The sugar beet cultivar Boro was planted 15 August 2014 using a Semeato 113 SHM 11/13 planter. Spacing was approximately $10 \mathrm{~cm}$ between 
Table 1. Chemical characteristics of the soil.

\begin{tabular}{cccccccccccc}
\hline & $\mathrm{pH}$ & $\mathrm{P}(\mathrm{melh})$ & $\mathrm{P}(\mathrm{rem})$ & $\mathrm{S} . \mathrm{SO} 4-2$ & $\mathrm{~K}$ & $\mathrm{Ca}$ & $\mathrm{Mg}$ & $\mathrm{Al}$ & $\mathrm{H}+\mathrm{Al}$ & $\begin{array}{c}\text { Organic } \\
\text { matter }\end{array}$ & $\begin{array}{c}\text { Organic } \\
\text { carbon }\end{array}$ \\
\hline $\mathrm{H} 2 \mathrm{O}$ & $\mathrm{CaCl} 2$ & \multicolumn{2}{c}{ mg.dm-3 (ppm) } & & & & cmol.dm-3 & & & g.dm-3 \\
5.5 & 4.8 & 4.6 & 2.8 & 7.0 & 0.29 & 1.7 & 0.5 & 0.0 & 4.3 & 29.0 & 16.8 \\
\hline
\end{tabular}

sugar beet plants within the same row, while the double rows were approximately $20 \mathrm{~cm}$ apart to provide a plant population of 500,000 plants ha $\mathrm{h}^{-1}$. Following typical production practices, sugar beet seedlings were thinned 25 days after emergence to a final plant population of 400,000 plants ha ${ }^{-1}$. At 45 days after emergence (DAE), $50 \mathrm{~kg} \mathrm{ha}^{-1}$ of urea $\left(22.5 \mathrm{~kg} \mathrm{ha}^{-1}\right.$ of $\left.\mathrm{N}\right)$ and $250 \mathrm{~kg} \mathrm{ha}^{-1}$ of $\mathrm{KCl}$ $\left(150 \mathrm{~kg} \mathrm{ha}^{-1}\right.$ of $\mathrm{K}_{2} \mathrm{O}$ ) were applied to the field to supplement the nutrient requirements of the crop. Plots were hand weeded as needed.

Sugar beet dry mass was determined at 15, 30, 45 and 60 DAE. Ten plants were collected randomly, oven dried with air circulation at $65{ }^{\circ} \mathrm{C}$ for 72 hours and weighed using an analytical balance. Sugar beet yield was determined at 75 DAE at crop maturity. Harvested roots were graded according to the CEAGESP guidelines for root equatorial diameter (CEAGESP, 2019): Extra A
(50 to $90 \mathrm{~mm}$ ) and Extra AA (91 to $110 \mathrm{~mm}$ ). The individual weight of each grade was recorded.

Data were subjected to an analysis of variance and regression. The means were compared by Tukey's test at a 5\% probability. The software used to perform statistical analysis was SISVAR version $12.0^{\circledR}$.

\section{Results and discussion}

The regression model for the accumulation of sugar beet dry mass during the growing season was similar for all treatments, with dry matter increasing from 15 to 45 DAE followed by a plateau between 45 and 60 DAE (Fig. 1). However, a trend was observed. The dry matter accumulation of beets decreased when grown in soil with a history of herbicide application.

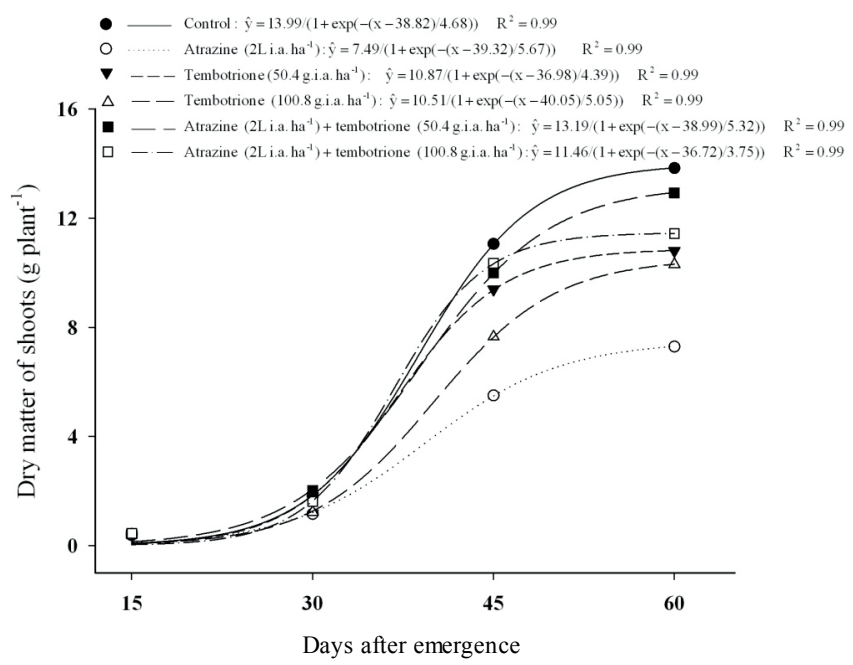

Figure 1. Aerial sugar beet dry biomass accumulation at 15, 30, 45 and 60 days after emergence in soil treated with atrazine and tembotrione 8 months before planting. 
In comparison to the control, atrazine reduced the dry biomass of sugar beet aerial parts in all evaluations (Table 2). By 60 DAE, in comparison to the control, the treatment with atrazine alone reduced the dry biomass of sugar beet by $47 \%$. Similar results were found for onions and carrots, which showed dry weight reductions of up to $23 \%$ and $33 \%$, respectively, compared to that of the control, when atrazine was applied in a previous year (Robinson, 2008). Sugar beet injury by atrazine was also verified by Demircioğlu (2007), who reported chlorosis, deformation and browning of leaves, stunting, and browning at the proximal end of the plant stem, which reduced the number of germinated seeds and dry and fresh root weight even when low doses of atrazine were used.
Simulated atrazine and tembotrione carryover reduced Extra A sugar beet yield but did not increase the amount of sugar beets discarded compared to that of the control (Table 3). Nelson and Penner (2005) evaluated sublethal doses of isoxaflutole applied at pre-emergence through irrigation water to alfalfa, carrot, cucumber, onion, beetroot, and tomato and noted that the use of doses substantially lower than those used for weed control in maize induced the test plants to show herbicide injury. However, clomazone at 1.1 or $2.2 \mathrm{~kg}$ a.i. ha ${ }^{-1}$ did not reduce the yield of sugar beet planted one or two years after application (Renner and Powell, 1991).

There are a few studies in the literature documenting tembotrione carryover in sugar beet. However,

Table 2. Sugar beet aerial dry biomass (g/plant) at 15, 30, 45 and 60 days after emergence of beet planted 8 months after atrazine and tembotrione application.

\begin{tabular}{|c|c|c|c|c|}
\hline \multirow{2}{*}{ Treatment } & \multicolumn{4}{|c|}{ Days after emergence } \\
\hline & 15 & 30 & 45 & 60 \\
\hline Control & $0.42 \mathrm{ab}^{*}$ & $1.81 \mathrm{ab}$ & $11.05 \mathrm{a}$ & $13.83 \mathrm{a}$ \\
\hline Atrazine ${ }^{\square}$ & $0.38 \mathrm{c}$ & $1.15 \mathrm{c}$ & $5.50 \mathrm{~b}$ & $7.29 \mathrm{~b}$ \\
\hline Tembotrione $^{\dagger}$ & $0.41 \mathrm{bc}$ & $1.80 \mathrm{ab}$ & $9.38 \mathrm{ab}$ & $10.80 \mathrm{ab}$ \\
\hline Tembotrione $e^{\ddagger}$ & $0.39 \mathrm{bc}$ & $1.22 \mathrm{bc}$ & $7.65 \mathrm{ab}$ & $10.30 \mathrm{ab}$ \\
\hline Atrazine + Tembotrione ${ }^{\dagger}$ & $0.43 \mathrm{ab}$ & $2.01 \mathrm{a}$ & $9.98 \mathrm{a}$ & $12.93 \mathrm{a}$ \\
\hline Atrazine + Tembotrione & $0.45 \mathrm{a}$ & $1.61 \mathrm{abc}$ & $10.34 \mathrm{a}$ & $11.42 \mathrm{a}$ \\
\hline $\mathrm{CV}(\%)$ & 4.10 & 17.07 & 26.58 & 14.27 \\
\hline
\end{tabular}

* Means followed by the same letter in the columns do not differ statistically by Tukey's test at $5 \%$ probability. ${ }^{\dagger}$ Tembotrione (50 g a.i. ha $\left.{ }^{-1}\right)$; ${ }^{\dagger}$ Tembotrione $\left(101 \mathrm{~g}\right.$ a.i. ha $\left.{ }^{-1}\right) ;{ }^{\square}$ Atrazine $\left(2 \mathrm{~kg}\right.$ a.i. ha $\left.{ }^{-1}\right)$. CV=Coefficient of variation.

Table 3. Yield of sugar beet roots planted 8 months after atrazine and tembotrione application by marketing class.

\begin{tabular}{|c|c|c|c|c|c|}
\hline \multirow[t]{2}{*}{ Treatment } & Extra $A^{* *}$ & Extra AA & Commercial & Discard & $\begin{array}{c}\text { Total } \\
(\text { Commercial }+ \\
\text { Discard })\end{array}$ \\
\hline & \multicolumn{5}{|c|}{$\mathrm{t} \mathrm{ha}^{-1}$} \\
\hline Control & $69.92 \mathrm{a}^{*}$ & $5.75 \mathrm{bc}$ & $75.65 \mathrm{a}$ & $4.42 \mathrm{a}$ & $80.11 \mathrm{a}$ \\
\hline Atrazine & $43.25 \mathrm{bc}$ & $4.77 \mathrm{bc}$ & $49.05 \mathrm{~b}$ & $8.20 \mathrm{a}$ & $56.24 \mathrm{bc}$ \\
\hline Tembotrione $^{\dagger}$ & $51.30 \mathrm{bc}$ & $13.72 \mathrm{ab}$ & $65.05 \mathrm{ab}$ & $9.05 \mathrm{a}$ & $74.11 \mathrm{ab}$ \\
\hline Tembotrione & $39.15 \mathrm{c}$ & $2.80 \mathrm{c}$ & $46.67 \mathrm{~b}$ & $8.72 \mathrm{a}$ & $55.41 \mathrm{c}$ \\
\hline Atrazine + Tembotrione $^{\dagger}$ & $54.67 \mathrm{abc}$ & $15.50 \mathrm{a}$ & $68.05 \mathrm{ab}$ & $9.42 \mathrm{a}$ & $77.53 \mathrm{a}$ \\
\hline Atrazine + Tembotrione & $56.77 \mathrm{ab}$ & $6.45 \mathrm{abc}$ & $65.12 \mathrm{ab}$ & $6.35 \mathrm{a}$ & $71.52 \mathrm{abc}$ \\
\hline $\mathrm{CV}(\%)$ & 14.26 & 51.17 & 15.93 & 43.43 & 11.86 \\
\hline
\end{tabular}

*Means followed by the same letter in the columns do not differ statistically by Tukey's test at $5 \%$ probability. **Extra A: 50 to $90 \mathrm{~mm}$; Extra AA: 91 to $110 \mathrm{~mm}$; Discard: roots defective or equatorial diameter of less than 50 mm. Tembotrione (50 g a.i. ha $\left.{ }^{-1}\right)$; ${ }^{\dagger}$ Tembotrione (101 g a.i. ha $\left.{ }^{-1}\right)$. 
some previous research has shown that this crop is sensitive to the herbicide and can be used as an indicator crop to determine the level of tembotrione residues in soil (Bontempo et al., 2016). Tembotrione is a weak acid herbicide with a $\mathrm{pKa}=4.22$, and the $\mathrm{pH} 5.5$ of the studied soil increases the proportion of herbicide molecules in a dissociated state. The sorption reduction of tembotrione in this type of clay soil is due repulsion among the negatives charges of soil and of the herbicide. Thus, tembotrione will be more prone to leach losses, which reduces its concentration at root absorption depths and may decrease herbicide injury in sensitive plants. However, in some cases, there is no correlation between herbicide sorption and clay concentration because the chemical properties of the clay depend on the source material and the degree of weathering, which can vary widely in tropical conditions. Additionally, in the summer of 2013/2014, rainfall was lower than the historical average rainfall, which might have reduced herbicide leaching.

Atrazine and tembotrione residues from the combined application did not reduce shoot dry matter or total sugar beet yield (Table 2, Table $3)$. The combined application of two or more herbicides may alter the efficiency of one of the molecules, either by additive, synergistic or antagonistic effects (Charles et al., 2018). Additive and synergistic effects have been reported for different mixtures of herbicides, for example, the combination of atrazine + diuron (Wilkinson et al., 2015), mesotrione + s-metolachlor (Carles et al., 2018), and atrazine + butachlor (Chen et al., 2015). However, other studies have shown antagonistic effects for glyphosate + cloransulam-methyl (Harre et al., 2018). In this work, the application of atrazine and tembotrione individually reduced the sugar beet root yield. However, the mixture of these herbicides with atrazine did not have the same effect, indicating that an antagonistic effect among atrazine and tembotrione may occur in the field or spray tank. These herbicides have different modes of action, but both affect the photosynthetic process of sensitive plants (Cooper et al., 2007). Tembotrione inhibits the synthesis of carotenoids, whereas atrazine affects the electron transport between PSII and PSI (Cooper et al., 2007). Therefore, the inhibition of carotenoids promoted by residues of tembotrione in soil, especially in new leaves, can reduce the formation of electrons in photosystem II, reducing the herbicidal action of atrazine. Bontempo et al., 2016 observed a similar effect for a carrot crop when atrazine and tembotrione were applied in a mixture.

We conclude that atrazine and tembotrione residues may negatively affect sugar beet yield when applied to corn 8 months prior to planting sugar beets. Based on these results, it has been suggested that sugar beet not be cultivated in an area treated with atrazine or tembotrione for at least eight months.

\section{Resumen}

G.D. Oliveira Pessoa Carneiro, A. Ferreira Bontempo, F.A. Rodrigues Guimarães, M. Rodrigues dos Reis, D. Valadão Silva, M. de Freitas Souza, y H. Anizio Lins. 2019. Arrastre de tembotriona y atrazina en la remolacha azucarera. Cien. Inv. Agr. 46(3): 319-324. Se realizó un experimento de campo con remolacha azucarera para determinar los efectos de los residuos de tembotriona y atrazina en el suelo, ocho meses después de la aplicación del herbicida. Los tratamientos incluyeron cultivo de remolacha azucarera con suelo contaminado con tembotriona (50.4 $\mathrm{g}$ ai ha-1 $)$, tembotrione (100.8 $\mathrm{g}$ ai ha $\left.{ }^{-1}\right)$, tembotriona y atrazina $(50.4 \mathrm{~g}$ ai

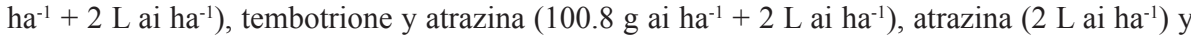
suelo sin aplicación de herbicida. En general, cuando se cultivó remolacha azucarera siguiendo cualquier tratamiento con herbicida, se redujo la biomasa seca del cultivo en comparación con el control. Sin embargo, solo los tratamientos rociados con alta tasa de tembotriona + 
atrazina disminuyeron significativamente el rendimiento de la remolacha azucarera. Por lo tanto, los residuos de atrazina + tembotriona en el suelo afectan negativamente el crecimiento y el rendimiento de la remolacha. Este estudio fue el primer informe que demostró que estos herbicidas pueden causar daños en la remolacha azucarera.

Palabras clave: Atrazina, Beta vulgaris L., arrastre, tembotrione.

\section{References}

Bontempo, A.F., G.D. Carneiro, F.A. Guimarães, M.R. Dos Reis, D.V. Silva, B.H. Rocha, M.F. Souza, and T. Sediyama. 2016. Residual tembotrione and atrazine in carrot. Journal of Environmental Science and Health Part B 51:465-468.

Companhia de Entrepostos e Armazéns Gerais de São Paulo - CEAGESP - Beterraba. http://www. ceagesp.gov.br/hortiescolha/hortifrutis/beterraba (accessed 29 Jan. 2019).

Carles, L., Joly, M., Bonnemoy, F., Leremboure, M., Donnadieu, F., Batisson, I., and Besse-Hoggan, P. 2018. Biodegradation and toxicity of a maize herbicide mixture: mesotrione, nicosulfuron and S-metolachlor. Journal of Hazardous Materials, 354:42-53.

Chen, C., Y. Wang, Y. Qian, X. Zhao, and Q. Wang. 2015. The synergistic toxicity of the multiple chemical mixtures: implications for risk assessment in the terrestrial environment. Environment international 77:95-105.

Cooper, R.L., S.C. Laws, P.C. Das, M.G. Narotsky, J.M. Goldman, E. Lee Tyrey, and T.E. Stoker. 2007. Atrazine and reproductive function: mode and mechanism of action studies. Birth Defects Research Part B: Developmental and Reproductive Toxicology 80:98-112.

Demircioğlu, A. 2007. Determination of the phytotoxic effects of some herbicides used on corn to sugar beet. http://agris.fao.org/agris-search/ search.do?recordID $=$ TR2011000839 (acessed 7 Dec. 2016).

Felix, J., and D.J. Doohan. 2005. Response of Five Vegetable Crops to Isoxaflutole Soil Residues. Weed technology 19:391-396.

Felix, J., D.J. Doohan, and D. Bruins. 2007. Differential vegetable crop responses to mesotrione soil residues a year after application. Crop protection 26:1395-1403.
Harre, N.T., J.M. Young, and B.G. Young 2018. Glyphosate-induced antagonism in rapid response giant ragweed (Ambrosia trifida). Weed Technology 32:52-59.

Ismail, B., and A. Ahmad. 1994. Attenuation of the herbicidal activities of glufosinate-ammonium and imazapyr in two soils. Agriculture, ecosystems \& environment 47:279-285.

Mancuso, M.A.C., E. Negrisoli, and L. Perim. 2011. Efeito residual de herbicidas no solo ("Carryover”). Revista Brasileira de Herbicidas 10:151164.

MAPA. Ministério da Agricultura e do abastecimento. Coordenação Geral de Agrotóxicos e Afins. http://agrofit.agricultura.gov.br/agrofit_ cons/!ap_produto_form_lista_cons (accessed 27 april 2019).

Nelson, E.A., and D. Penner. 2005. Sensitivity of Selected Crops to Isoxaflutole in Soil and Irrigation Water. Weed technology 19:659-663.

Renner, K.A., and G.E. Powell. 1991. Response of sugarbeet (Beta vulgaris) to herbicide residues in soil. Weed technology 622-627.

Robinson, D.E. 2008. Atrazine accentuates carryover injury from mesotrione in vegetable crops. Weed technology 22:641-645.

Silva, V., L. Ferreira, L. D’Antonino, J. Carneiro, G. Silva, and D. Fontes, 2013. Efficiency and soil residual effect of herbicides in bean culture. Planta Daninha 31:961-970.

USDA, 2015. Commercial Vegetable Production Recommendations. http://pubs.ext. vt.edu/456/456-420/456-420-pdf.pdf (accessed 7 Dec. 2016).

Wilkinson, A.D., C.J. Collier, F. Flores, and A.P. Negri. 2015. Acute and additive toxicity of ten photosystem-II herbicides to seagrass. Scientific reports 5:17443. 